\title{
Dendritic GluN2A Synthesis Mediates Activity-Induced NMDA Receptor Insertion
}

\author{
Sharon A. Swanger, ${ }^{1}$ Yuncen A. He, ${ }^{1}$ Joel D. Richter, ${ }^{3}$ and Gary J. Bassell ${ }^{1,2}$ \\ Departments of ${ }^{1}$ Cell Biology and ${ }^{2}$ Neurology, Emory University School of Medicine, Atlanta, Georgia 30322, and ${ }^{3}$ Program in Molecular Medicine, \\ University of Massachusetts Medical School, Worcester, Massachusetts 01605
}

Long-term synaptic plasticity involves changes in the expression and membrane insertion of cell-surface proteins. Interestingly, the mRNAs encoding many cell-surface proteins are localized to dendrites, but whether dendritic protein synthesis is required for activityinduced surface expression of specific proteins is unknown. Herein, we used microfluidic devices to demonstrate that dendritic protein synthesis is necessary for activity-induced insertion of GluN2A-containing NMDA receptors in rat hippocampal neurons. Furthermore, visualization of activity-induced local translation of GluN2A mRNA and membrane insertion of GluN2A protein in dendrites was directly observed and shown to depend on a $3^{\prime}$ untranslated region cytoplasmic polyadenylation element and its associated translation complex. These findings uncover a novel mechanism for cytoplasmic polyadenylation element-mediated posttranscriptional regulation of GluN2A mRNA to control NMDA receptor surface expression during synaptic plasticity.

\section{Introduction}

Long-term plasticity at glutamatergic synapses depends on both the regulation of glutamate receptor trafficking and dendritic protein synthesis, yet how these processes might be linked remains unclear (Sutton and Schuman, 2006; Rebola et al., 2010). The AMPA and NMDA families of ionotropic glutamate receptors are critical mediators of long-term synaptic plasticity and are dynamically regulated at synapses (Derkach et al., 2007; Santos et al., 2009). Several reports suggest that AMPA receptor expression and membrane insertion may be regulated by dendritic mRNA localization and local protein synthesis (Kacharmina et al., 2000; Ju et al., 2004; Smith et al., 2005; Grooms et al., 2006; Sutton et al., 2006; Maghsoodi et al., 2008; Soden and Chen, 2010). However, whether dendritic protein synthesis regulates NMDA receptor expression or membrane insertion is unknown.

NMDA receptors are composed of two GluN1 and two GluN2 subunits (types 2A-2D). Hippocampal pyramidal neurons express the GluN2A and GluN2B subunits, which have distinct functional properties and are differentially expressed during development (Traynelis et al., 2010). Furthermore, the relative surface level of GluN2A-containing and GluN2B-containing

\footnotetext{
Received Jan. 21, 2013; revised March 28, 2013; accepted April 15, 2013.

Author contributions: S.A.S., J.D.R., and G.J.B. designed research; S.A.S. and Y.A.H. performed research; S.A.S., Y.A.H., and G.J.B. analyzed data; S.A.S. and G.J.B. wrote the paper.

We gratefully acknowledge support from the NIH, Grants F31NS063668, T32GM0860512, and T32NS007480 (S.A.S.), and MH085617 (G.J.B.), the Epilepsy Foundation and Lennox and Lombroso Trust Fund (S.A.S.), and NARSAD (G.J.B.). This research was also supported in part by the Emory University Integrated Cellular Imaging Microscopy Core of the Emory Neuroscience NINDS Core Facilities Grant, P30NS055077. We thank Dr Tsuyoshi Udagawa for lentiviral shRNAs, Dr Wilfried Rossoll for assistance with microfluidic devices, Dr Lori Lorenz for insights into Ngd activity, and Drs Christina Gross and Bart Anderson for critically reading the paper.

The authors declare no competing financial interests.

Correspondence should be addressed to Dr Gary J. Bassell, Emory University School of Medicine, Whitehead Biomedical Research Building, Room 415, 615 Michael St NE, Atlanta, GA, 30322. E-mail: gary.bassell@emory.edu. DOI:10.1523/JNEUROSCI.0289-13.2013

Copyright $\odot 2013$ the authors $\quad 0270-6474 / 13 / 338898-11 \$ 15.00 / 0$
}

NMDA receptors affects neuronal function (Lau and Zukin, 2007). Therefore, it is important to understand the mechanisms regulating GluN2 subunit expression and membrane insertion. Similar to AMPA receptors, synaptic activity regulates the expression and trafficking of NMDA receptors (Lau and Zukin, 2007; Yashiro and Philpot, 2008; Smith et al., 2009). Activitydependent plasticity in the hippocampus involves increased NMDA receptor-surface expression (Grosshans et al., 2002; Kwon and Castillo, 2008; Rebola et al., 2008). The NMDA receptor component of EPSPs is increased during long-term potentiation (LTP) in the dentate gyrus, and this effect is mediated by GluN2A-containing receptors (Peng et al., 2010). Interestingly, LTP in the hippocampus and sensory activation of the visual cortex lead to increased GluN2A protein expression (Williams et al., 1998,2003; Quinlan et al., 1999; Zhong et al., 2006; Philpot et al., 2007). However, the posttranscriptional mechanisms underlying activity-induced expression of NMDA receptor subunits are unclear.

Recently, we reported that GluN2A mRNA contains a cytoplasmic polyadenylation element (CPE) in its $3^{\prime}$ untranslated region (UTR), and GluN2A protein expression is bidirectionally regulated by two translation factors associated with the $\mathrm{CPE}$ binding (CPEB) protein, namely Gld2, a poly(A) polymerase, and neuroguidin $(\mathrm{Ngd}$ ), an eIF4E-binding protein (Udagawa et al., 2012). Gld2 and Ngd also bidirectionally regulate theta-burst LTP in the dentate gyrus (Udagawa et al., 2012). Notably, GluN2A mRNA is localized to hippocampal neuron dendrites, suggesting that it could be locally translated (Cajigas et al., 2012; Udagawa et al., 2012). CPEB and associated factors are also localized to dendrites (Udagawa et al., 2012), but whether they regulate GluN2A mRNA localization or dendritic translation has not been studied. Moreover, whether the CPEB-associated translation complex regulates NMDA receptor-surface expression is unknown. Here, we tested the hypothesis that CPEB-mediated 
dendritic synthesis of GluN2A regulates activity-induced NMDA receptor insertion. Our findings demonstrate a requirement for dendritic protein synthesis and the CPEB-associated translation complex in the activity-dependent synthesis and membrane insertion of GluN2A in dendrites.

\section{Materials and Methods}

Cell culture and drug treatments. Hippocampal neuron cultures were prepared from Sprague Dawley rat embryos of either sex at day E18, as described previously (Goslin and Banker, 1998). Neurons were cultured for 21-24 d in vitro (DIV) on poly-L-lysine-coated tissue culture plastic for biochemical experiments and glass coverslips for imaging experiments. Neuro 2A cells, a mouse neuroblastoma cell line, were cultured in DMEM (Sigma-Aldrich) with 10\% FBS (Hyclone) and grown on tissue culture plastic.

For glycine stimulation experiments, hippocampal neurons were incubated in extracellular solution lacking magnesium (in mм: $150 \mathrm{NaCl}, 2$ $\mathrm{CaCl}_{2}, 5 \mathrm{KCl}, 10$ HEPES, 30 glucose, 0.0005 TTX, 0.001 strychnine, 0.02 bicuculline methiodide, $\mathrm{pH}$ 7.4) for $30 \mathrm{~min}$, and then extracellular solution plus $200 \mu \mathrm{M}$ glycine for $3 \mathrm{~min}$. Glycine solution was then removed and neurons were incubated in extracellular solution (without glycine) for $30 \mathrm{~min}$. Control groups had solution changes at each time point, but were not treated with glycine. For anisomycin experiments, $40 \mu \mathrm{M}$ anisomycin or equal volume of DMSO was applied to neurons for $30 \mathrm{~min}$ before glycine stimulation and kept in the solution throughout each experiment.

Microfluidic devices. Neurons were cultured in microfluidic devices (RD150, Xona Microfluidics) for 25-28 DIV as per the manufacturer instructions and culture conditions described above. Briefly, microfluidic devices were sterilized with $70 \%$ ethanol and adhered to poly-Llysine-coated coverslips $(25 \mathrm{~mm})$. Hippocampal neurons were suspended in plating media at 4 million cells per milliliter, and $15 \mu \mathrm{l}$ of the suspension was plated in the microfluidic device. After $30 \mathrm{~min}$, both sides of the device were filled with culture media. Half of the media was exchanged on each side two times per week for the first 2 weeks, and then every $2 \mathrm{~d}$ thereafter. For drug treatments, media on both sides was replaced with extracellular solution (see above) $30 \mathrm{~min}$ before glycine stimulation. In anisomycin experiments, anisomycin-containing or DMSO-containing solution was added to the cell body or dendrite side for $30 \mathrm{~min}$. For glycine stimulation, the extracellular solution was removed and glycine-containing solution (or control) was added to the dendrite side for $3 \mathrm{~min}$, and then replaced with extracellular solution (without glycine) for $30 \mathrm{~min}$. To ensure that microfluidic isolation was maintained during this treatment protocol, we used time-lapse imaging and PBS containing Cy3 or Cy5 dye (GE Healthcare) to visualize a mock glycine-induced LTP paradigm in the microfluidic device (see Fig. 2C). For immunostaining, the neurons were fixed in the microfluidic devices, washed two times with PBS, and then the microfluidic device was removed from the glass coverslip.

DNA constructs and shRNA lentivirus. A 933 nucleotide sequence of the GluN2A 3' UTR was cloned from rat brain cDNA using the following primers: $5^{\prime}$-cgcgcgctcgagatgtggctcagatgctttcc-3', 5'-cgcgcgtccggatttctc attttcatatcaattggcag- $3^{\prime}$. Within the cloned portion of the GluN2A $3^{\prime}$ UTR, the CPE sequence (UUUUUAAUU) was mutated to GGATCCAUU using QuikChange XL (Agilent) and the following primers: $5^{\prime}$ gaagtatatactatggttgtcttcttgtagtatgtctggtaccattttgttcaatgtgatatcaactgttttaag gaatg- $3^{\prime}$, and $5^{\prime}$-cattccttaaaacagttgatatcacattgaacaaaatggtaccagacatactaca agaagacaaccatagtatatacttc- $3^{\prime}$. The $3^{\prime}$ UTR sequences were confirmed by sequencing (Agencourt). The 3' UTRs were cloned into peGFP-C1 (Clontech) and Pal2-Dendra2-C1(Welshhans and Bassell, 2011) using BspE1 and XhoI sites. A portion of the $5^{\prime}$ UTR $(-1352--338)$ was a gift from G. Bai (University of Maryland). PCR was used to add NheI and AgeI restriction sites flanking the $5^{\prime}$ UTR using the following primers: $5^{\prime}$-gcgcgcgctagcgcagcaagtgtgtatgtgtgt- $3^{\prime}$, and $5^{\prime}$-gcgcgcaccggtgagccctgg ctcagctttct- $3^{\prime}$. The 5' UTR was cloned upstream of Pal2-Dendra2. Superecliptic phluorin (SEP)-tagged GluN2A was purchased from Addgene (plasmid 23997; Kopec et al., 2006). To make the SEP-GluN2A-3' UTR construct, the GluN2A 3' UTR and GluN2A- $\Delta$ CPE sequences were cut from the Pal2-Dendra2-3' UTR plasmids using XhoI/Bsp1201, and then blunt ligated with NotI digested SEP-GluN2A. FLAG-CPEB constructs were previously described (Udagawa et al., 2012). Lentiviruses were generated from pLentilox 3.7 shRNA plasmids as described previously (Udagawa et al., 2012). Concentrated lentivirus was delivered to hippocampal cultures for 3-4 d, and protein knockdown was analyzed by Western blotting (see Fig. 3E) (Udagawa et al., 2012). Based on GFP expression, we estimated the transduction efficiency as $70-80 \%$ in $17-21$ DIV cultures.

Antibodies. For total and surface immunofluorescence studies, the following primary antibodies were used: anti-GluN2A (1:100, Alomone Labs), anti-GluN2B (1:100, Alomone Labs), anti-GluN1 (1:100, BD Bioscience), and anti-MAP2 (1:1000, Sigma-Aldrich). The secondary antibodies used were donkey anti-rabbit-Cy2 or -Cy3 and donkey antimouse-Cy2 or -Cy5 (Jackson Immunoresearch). For Western blotting, the following primary antibodies were used: anti-GluN2A (1:500, Millipore), anti-GluN2B (1:500, Millipore), anti-GluN1 (1:2000), and anti$\alpha$-tubulin (1:20,000, Sigma-Aldrich). The secondary goat anti-mouse and goat anti-rabbit HRP-conjugated antibodies were used at 1:5000 (GE Healthcare).

Immunofluorescence. Cultured hippocampal neurons were processed for cell-permeable immunostaining as described previously (Muddashetty et al., 2007), and the following modifications were made for surface immunostaining. After fixation, the neurons were blocked in $2 \%$ bovine serum albumin (BSA) fraction V and 2\% FBS in Tris-buffered saline (TBS) without Triton X-100. The primary and secondary antibody incubations were done in 1\% BSA and $1 \%$ FBS in TBS for $1 \mathrm{~h}$ at room temperature. For concurrent MAP2 immunostaining, cells were permeabilized with $0.3 \%$ Triton X-100 in TBS for 10 min after incubation with the surface antibodies. The cells were incubated with anti-MAP2 antibody in buffer containing $0.1 \%$ Triton X-100, and then both secondary antibody incubations were done in buffer containing $0.1 \%$ Triton X-100.

Fluorescence in situ hybridization. Cultured hippocampal neurons were processed for FISH as described previously (Swanger et al., 2011). Antisense oligonucleotide sequences for GluN2A mRNA probes were previously reported (Udagawa et al., 2012). GFP probes are as follows: 5' gtggtgcagatgaacttcagggtcagcttgccgtaggtgg $3^{\prime}, 5^{\prime}$ ggcggatcttgaagttcaccttgatgccgttcttctgctt $3^{\prime}$, and $5^{\prime}$ cacgaactccagcaggaccatgtgatcgcgcttctcgttg $3^{\prime}$. The bold thymidine residues are those that were amino-modified allowing conjugation of fluorophores.

FLAG immunoprecipitations and RNA extraction. Hippocampal neurons or Neuro 2A cells were lysed with buffer containing the following: $150 \mathrm{~mm} \mathrm{NaCl}, 50 \mathrm{~mm}$ Tris, $1 \mathrm{~mm} \mathrm{MgCl}_{2}$, protease inhibitors (Roche), RNase inhibitors (Promega), and 1\% Nonidet P40, pH 7.4. Agarose beads conjugated to anti-FLAG antibodies (Sigma-Aldrich) were washed 3 times with PBS, and then incubated with cell lysates for $2 \mathrm{~h}$ rotating at $4^{\circ} \mathrm{C}$. Five percent of the input was kept for analysis of total mRNA. The beads were washed four times with lysis buffer. RNA was extracted from the input and IP samples using Trizol LS (Invitrogen) according to the manufacturer's instructions.

Quantitative real-time PCR. mRNAs were reverse transcribed with random hexamer primers by Superscript III (Invitrogen) according to the manufacturer's instructions. PCR was performed in triplicate with specific primers and SYBR II dye in a light cycler (Roche). The primers used are as follows: GluN2A: gggctgctcttctccatcagc, cccttgtctgaaaccatgtccac; GluN1: tctggccaggaggagagacagag, tgtcattaggccccgtacagatcacc; $\gamma$-actin: ctggtggatctctgtgagcac, aaacgttcccaactcaaggc; $\alpha$ CaMKII: gctgccaagattatcaacacc, cac gctccagcttctggt; GFP: aaggacgacggcaactacaag, atgccgttcttctgcttgtcg; Dendra2: ccggttcttttgtcaagacc, ctgcctcgtcttgcagttc.

Surface biotinylation. Surface protein biotinylation was performed as previously described (Ehlers, 2000). Briefly, high density hippocampal neuron cultures were placed on ice and rinsed twice with ice-cold PBS containing $1 \mathrm{~mm} \mathrm{MgCl}$ and $0.01 \mathrm{mM} \mathrm{CaCl}_{2}$, then incubated on ice with $\mathrm{PBS} / \mathrm{MgCl}_{2} / \mathrm{CaCl}_{2}$ containing $1 \mathrm{mg} / \mathrm{ml}$ Sulfo-NHS-Biotin (Thermo Scientific) for $20 \mathrm{~min}$. Cultures were then rinsed 3 times with $\mathrm{PBS} / \mathrm{MgCl}_{2} /$ $\mathrm{CaCl}_{2}$ containing $50 \mathrm{~mm}$ glycine to quench the biotin reactivity. Neurons were scraped in ice-cold lysis buffer (in mM: $150 \mathrm{NaCl}, 50$ Tris, 5 EDTA, 5 EGTA, $50 \mathrm{NaF}, 10$ sodium pyrophosphate, $1 \%$ Triton, $0.2 \%$ SDS, and protease inhibitors), then sonicated and centrifuged for $15 \mathrm{~min}$. Super- 
natants were added to neutravidin beads and rotated at $4^{\circ} \mathrm{C}$ for $2 \mathrm{~h}$, then washed 4 times with lysis buffer; $2 \%$ of the supernatant volume was kept for SDS-PAGE analysis. Laemmli buffer was added to the samples, and they were boiled for $5 \mathrm{~min}$, followed by SDS-PAGE and Western blotting.

Synaptoneurosome preparation. Synaptoneurosomes were prepared from male C57BL/6 mice at postnatal day $18-21$ as described previously (Hollingsworth et al., 1985; Scheetz et al., 2000). Briefly, the dissected hippocampus was homogenized on ice in 10 volumes of homogenization buffer containing the following (in $\mathrm{mm}$ ): $118 \mathrm{NaCl}, 4.7 \mathrm{KCl}, 1.2 \mathrm{MgSO}_{4}$, $2.5 \mathrm{CaCl}_{2}, 1.53 \mathrm{KH}_{2} \mathrm{PO}_{4}, 212.7$ glucose, and 1 DTT, $\mathrm{pH} 7.4$, and supplemented with complete protease inhibitors (Roche). A sample of the total homogenate was removed and kept on ice. The homogenate was passed through three $100 \mu \mathrm{m}$ nylon mesh filters, followed by one $11 \mu \mathrm{m}$ filter (Millipore) and centrifuged at $1000 \times g$ for $10 \mathrm{~min}$. The synaptoneurosome pellets were resuspended in the same buffer. Protein concentrations were estimated using the Bradford protein assay (Bio-Rad). Samples were incubated at $37^{\circ} \mathrm{C}$ for $15 \mathrm{~min}$ with vehicle or anisomycin, and then treated for $15 \mathrm{~min}$ with $100 \mu \mathrm{M}$ glutamate and $50 \mu \mathrm{M}$ glycine. Laemmli buffer was added to the samples, which were then boiled for 5 min and processed by SDS-PAGE.

Fixed image acquisition and analysis. Cultured neurons were imaged with a Nikon Ti inverted microscope using a $60 \times 1.4$ NA Plan Apo objective and an HQ2 cooled CCD camera (Photometrics). Within each experiment, all treatment groups were imaged with the same acquisition settings and within the same imaging session. $Z$-series were obtained at $0.15 \mu \mathrm{m}$ steps. Image stacks were deconvolved using a 3-D blind constrained iterative algorithm (AutoQuant, CyberMetrics). Quantification of immunofluorescence and FISH signals was performed using ImageJ (version 1.46j). Mean fluorescence intensities were quantified within a cellular region, and mean background fluorescence intensities were quantified from an adjacent, noncellular region. Dendrites were straightened using the Straighten plugin in ImageJ. For dendritic granule counts, a dendritic region was chosen in ImageJ and a threshold level was determined that included all granules above background. The threshold was applied and the Particle Analysis function was used to compute the number of granules within the area. The same threshold was used across all images and groups. The representative images shown within a single figure panel are presented with identical lookup table settings. The experimenter was blind to the treatment conditions during image acquisition and analysis.

Live-cell imaging. A Nikon A1R microscope, NIS-Elements software, and a $60 \times$ objective (Apo TIRF, NA 1.49) were used for live-cell imaging. The neurons were maintained at $37^{\circ} \mathrm{C}$ and $5 \% \mathrm{CO}_{2}$ throughout the experiment. Thirty minutes before imaging, the growth media was removed and exchanged with extracellular solution (without glycine). For some experiments, neurons were pretreated with anisomycin $(40 \mu \mathrm{m})$ or vehicle control (DMSO) during this 30 min period. For translation assays, neurons were transfected with the Dendra2 reporter constructs using Lipofectamine 2000 and were used for imaging $48 \mathrm{~h}$ after transfection. Distal dendritic regions were chosen on 3 or 4 neurons, and an initial image of each region was taken using the 488 and $561 \mathrm{~nm}$ lasers. Glycine-containing solution or vehicle was applied to the neurons (time point: $0 \mathrm{~min}$ ), and then the regions were photoconverted using the 405 nm laser. After $3 \mathrm{~min}$, the solution was changed to extracellular solution without glycine. Each region was imaged every 5 min with the 488 and $561 \mathrm{~nm}$ lasers for $60 \mathrm{~min}$. For a photoconverted dendritic region to be included in the analysis, the $488 \mathrm{~nm}$ signal had to decrease by $75 \%$ and the $561 \mathrm{~nm}$ signal had to increase by $50 \%$. Mean fluorescence intensity was measured in the dendritic region at each time point and background subtracted. In each experiment, green fluorescence was measured outside of the photoconverted region to control for photobleaching, and red fluorescence was measured within the photoconverted region to monitor Dendra2 diffusion. For surface expression assays, cultured neurons were transfected with SEP-GluN2A and FLAG-mCherry using Lipofectamine 2000 at 17 DIV and imaged 18-24 h later. FLAG-mCherry was used to identify transfected neurons. Dendritic regions were chosen on 3 or 4 neurons and then imaged using the 488 and $561 \mathrm{~nm}$ lasers every $5 \mathrm{~min}$ for $30 \mathrm{~min}$. To measure SEP fluorescence, a dendritic region was traced using the mCherry signal and a threshold level was determined that included all
SEP fluorescence puncta above background. The threshold was applied and the Particle Analysis function was used to compute total fluorescence in the threshold region. The same threshold was used across each time point within one experiment. For all experiments, the intensity measurements were normalized to the first image acquired following addition of glycine or vehicle and graphed as $\Delta F / F_{\text {initial }} \times 100$. For the Dendra2 experiments, $F_{\text {initial }}$ is the fluorescence at $5 \mathrm{~min}$, and for the SEP experiments, $F_{\text {initial }}$ is the fluorescence at $0 \mathrm{~min}$. The experimenter was blind to treatment condition during image analysis.

Statistical analysis. Each experiment was repeated a minimum of three independent times and all analysis was completed using SPSS (IBM). All datasets were analyzed for normality using the Shapiro-Wilk test. If the data were normally distributed then a Student's $t$ test or ANOVA (oneway, two-way, or repeated-measures) was performed. Significant ANOVA analyses were followed by post hoc tests as mentioned in each figure legend. If the data were not normally distributed, then the nonparametric Mann-Whitney or Kruskal-Wallis test was performed. The specific statistical test used in each experiment is given in its figure legend. Significance was set as $p \leq 0.05$ and adjusted for the number of pairwise comparisons when necessary. All data are graphed as mean \pm SEM.

\section{Results}

Protein synthesis regulates activity-induced surface expression of GluN2A-containing NMDA receptors

To investigate activity-induced NMDA receptor expression in cultured hippocampal neurons, we used an established NMDA receptor-dependent form of glycine-induced LTP (Lu et al., 2001; Park et al., 2006). Although glycine-induced LTP has been shown to increase surface expression of AMPA receptor subunits (Lu et al., 2001), the effects on total and surface expression of specific NMDA receptor subunits have not been studied. In surface protein biotinylation assays, GluN1 and GluN2A surface expression was significantly increased $30 \mathrm{~min}$ after glycine application, and these effects were blocked by the protein synthesis inhibitor anisomycin (Fig. $1 A, B$ ). Glycine also increased total GluN1 and GluN2A protein levels in a protein synthesisdependent manner (Fig. 1C). In contrast, total and surface levels of GluN2B were unaffected by glycine treatment (Fig. $1 A-C$ ). These results indicate that the ratio of GluN2A to GluN2B surface levels increased by $30 \%$. Similarly, surface immunolabeling and quantitative imaging demonstrated that glycine increased GluN1 and GluN2A surface expression in dendrites and that these effects were blocked by anisomycin (Fig. $1 D, E$ ). In contrast, dendritic surface expression of GluN2B was not affected by glycine or anisomycin (Fig. $1 F$ ). Together, these data indicate that glycine treatment increases the dendritic surface expression of GluN2Acontaining NMDA receptors in a protein synthesis-dependent manner.

\section{Dendritic protein synthesis is required for glycine-induced GluN2A surface expression}

Dendritic protein synthesis is necessary for certain types of LTP (Kang and Schuman, 1996; Cracco et al., 2005; Huang and Kandel, 2005; Vickers et al., 2005) and regulates AMPA receptor surface expression (Kacharmina et al., 2000; Ju et al., 2004; Maghsoodi et al., 2008; Soden and Chen, 2010). Given that NMDA receptor-surface expression is also activity-regulated and GluN2A mRNA is localized to dendrites (Cajigas et al., 2012; Udagawa et al., 2012), we hypothesized that dendritic protein synthesis could mediate the insertion of GluN2A-containing NMDA receptors during glycine-induced LTP. To test whether dendritic protein synthesis is necessary for glycine-induced NMDA receptor expression and membrane insertion, neurons were cultured in microfluidic devices that allow for separate 
A

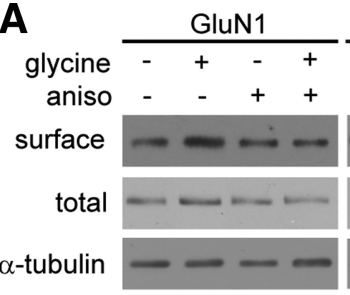

B

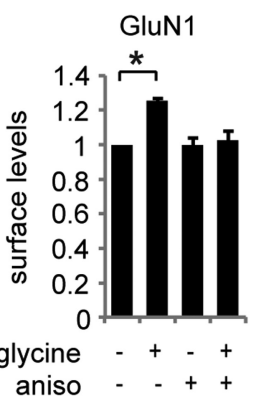

C

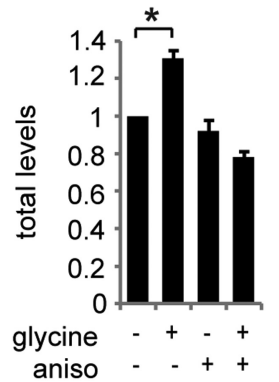

GluN2A

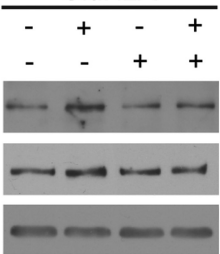

GluN2A
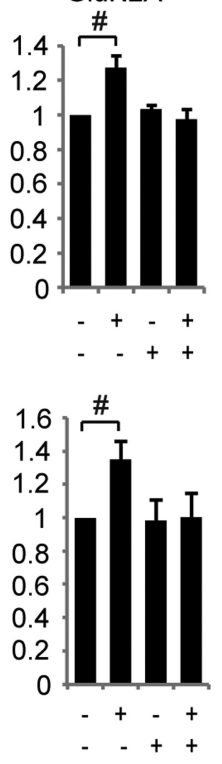

GluN2B

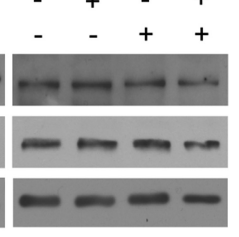

GluN2B
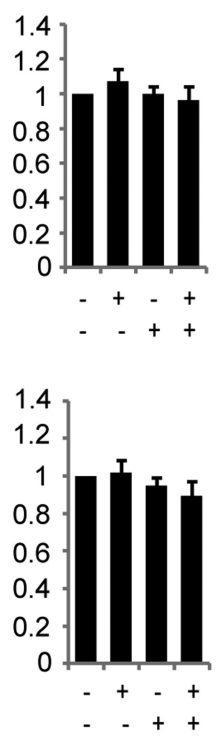

\section{D}

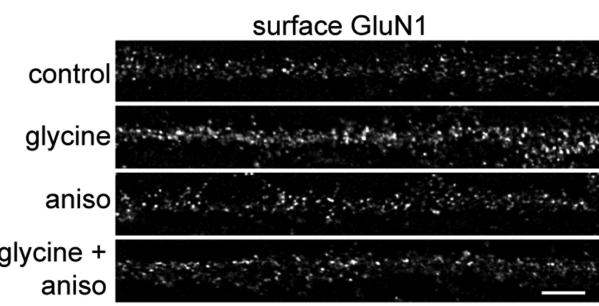

surface GluN2A

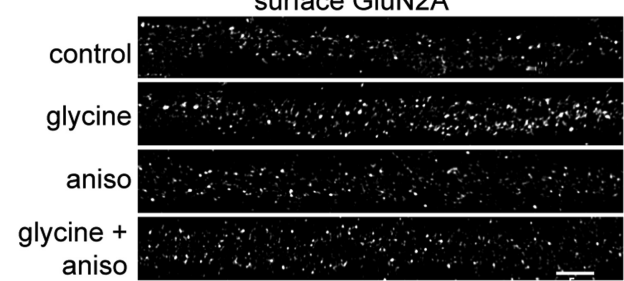

$\mathbf{F}$

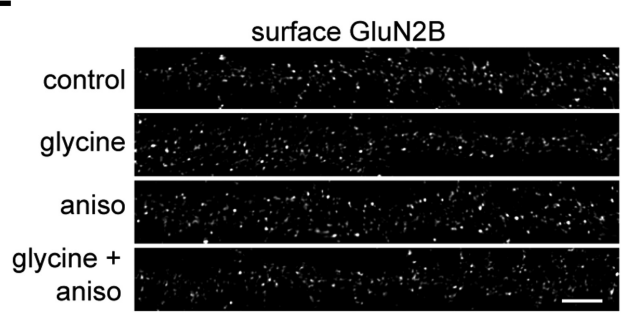

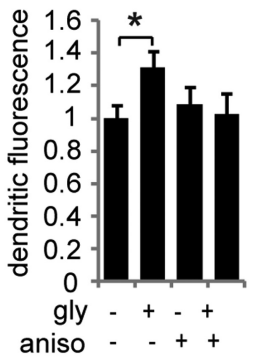

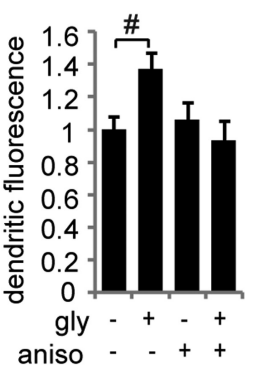

aniso

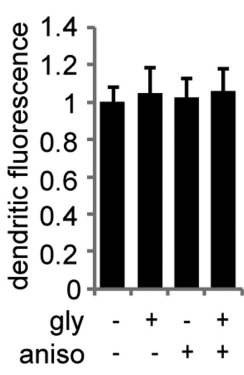

Figure 1. Glycine induced a protein synthesis-dependent increase in GluN2A-containing NMDA receptor surface expression. A, Hippocampal neurons were pretreated with anisomycin (aniso) or DMSO for $30 \mathrm{~min}$, treated with glycine or vehicle for $3 \mathrm{~min}$, and then incubated without glycine for $30 \mathrm{~min}$. Anisomycin or DMSO was present in all solutions. Total and biotinylated surface levels of GluN1, GluN2A, and GluN2B levels were measured by Western blotting (repeated-measures ANOVA, Bonferroni $t$ tests, $n=6 ; \boldsymbol{B},{ }^{*} p=0.001, \# p=0.022 ; \boldsymbol{C},{ }^{*} p=0.020,{ }^{\#} p=0.015$ ). $\boldsymbol{D}-\boldsymbol{F}$, Hippocampal neurons were treated with anisomycin, followed by glycine-induced LTP, and then surface GluN1, GluN2A, or GluN2B were immunolabeled. Scale bar, $5 \mu$ m. Graphed values are dendritic fluorescence intensities normalized to the control group mean (ANOVA, Bonferroni $t$ tests, $n=45-53 ;{ }^{*} p=0.022 ;{ }^{\sharp} p=0.012$ ). Graphed data are mean \pm SEM.

pharmacological treatment of cell bodies and distal dendrites (Fig. 2A,B) (Taylor et al., 2005). Fluorescent dyes and time-lapse imaging were used to ensure that fluidic isolation was maintained throughout the glycine treatment paradigm (Fig. 2C). Glycine application to the dendritic compartment significantly increased dendritic GluN2A surface expression 30 min after the glycine treatment. Anisomycin blocked this effect when locally applied to dendrites, but not when applied to cell bodies (Fig. 2D). These data suggest that dendritic protein synthesis is necessary for the insertion of GluN2A-containing NMDA receptors during glycine-induced LTP. In microfluidic devices, glycine application to dendrites also increased total dendritic GluN2A levels (Fig. $2 E)$. Importantly, anisomycin application to the cell body compartment did not abolish the glycine-induced increase in total dendritic GluN2A expression, although overall GluN2A levels were decreased (Fig. 2E). Anisomycin treatment to dendrites did not affect basal GluN2A levels, but led to a glycine-induced decrease in total dendritic GluN2A levels (Fig. 2E). This observation suggests that glycine treatment to dendrites may lead to the turnover of GluN2A, which would be replaced by newly synthesized subunits; although, the mechanisms underlying this are unknown. Importantly, these data indicate that dendritic protein synthesis is required for glycine-induced GluN2A expression, whereas somatic protein synthesis regulates constitutive GluN2A protein levels in dendrites.
CPEB and the CPE sequence regulate dendritic GluN2A mRNA localization

We previously reported that the GluN2A 3' UTR contains a CPE sequence (Udagawa et al., 2012), yet the role of CPEB and the $3^{\prime}$ UTR CPE sequence in regulating GluN2A translation has not been studied. The CPEB-associated translation complex is localized to dendrites and dendritic spines, and CPEB as well as CPE sequences have been shown to regulate dendritic mRNA localization and local translation (Wells et al., 2001; Huang et al., 2003; Udagawa et al., 2012). Therefore, we hypothesized that the CPE sequence and associated factors modulate NMDA receptorsurface expression in dendrites by controlling the dendritic localization and local translation of GluN2A mRNA. To test this hypothesis, we first investigated the interaction between CPEB and GluN2A mRNA. In cultured hippocampal neurons, FLAG-tagged CPEB immunoprecipitated endogenous GluN2A mRNA as well as $\alpha$ CaMKII mRNA, a known CPEB target mRNA, whereas GluN1 and $\gamma$-actin mRNAs were not immunoprecipitated (Fig. $3 A$ ). In a neuroblastoma cell line, FLAG-CPEB immunoprecipitated a portion of the GluN2A 3' UTR containing the CPE sequence, but not the $3^{\prime}$ UTR with a mutated CPE sequence ( $\triangle \mathrm{CPE}$ GluN2A) (Fig. $3 B, C$ ). These data suggest that CPEB associates with GluN2A mRNA via the $3^{\prime}$ UTR CPE sequence.

Given that CPEB has been shown to interact with kinesin and to regulate mRNA transport (Huang et al., 2003), we assessed 

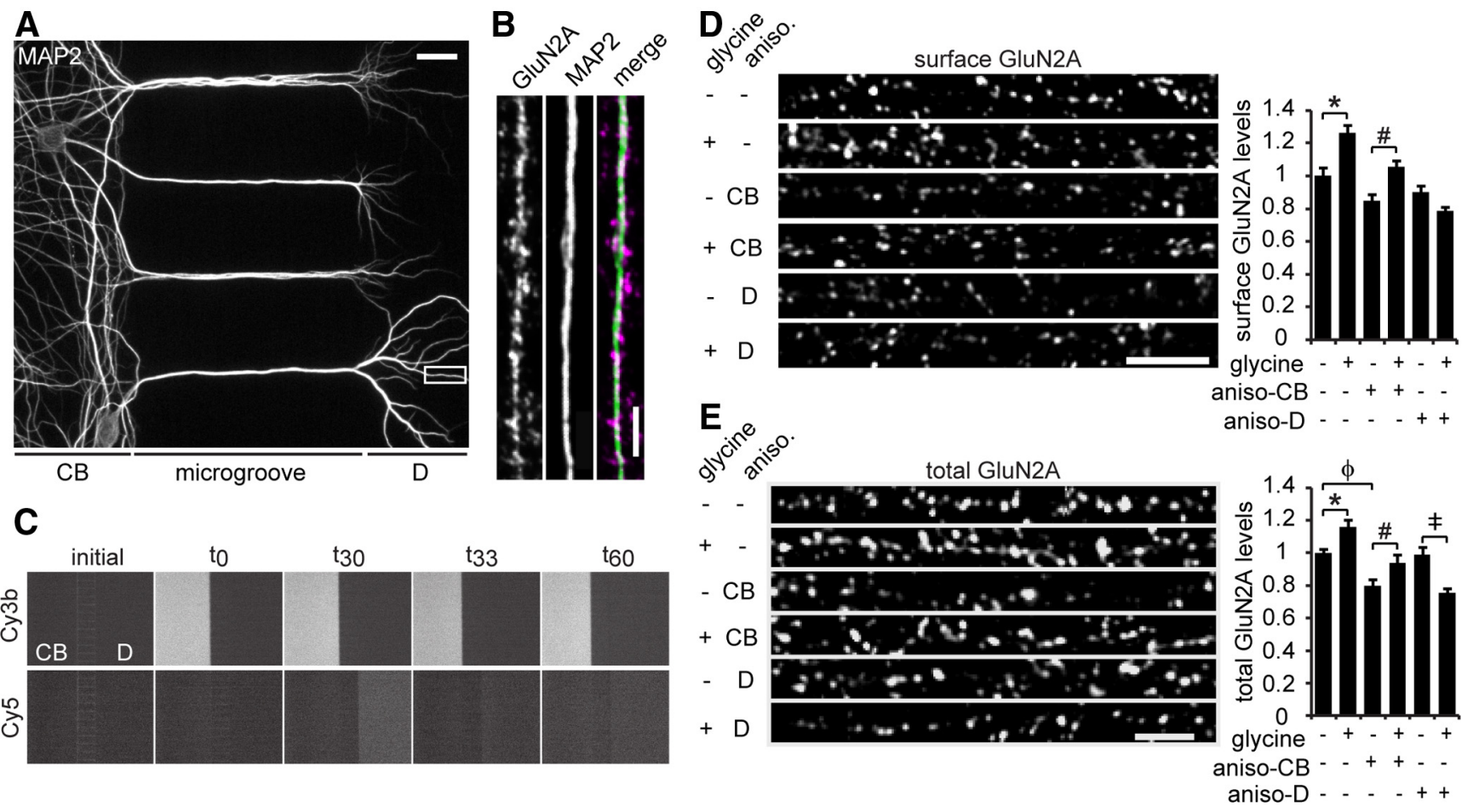

Figure 2. Dendritic protein synthesis is required for glycine-induced insertion of GluN2A. A, MAP2 staining of 25 DIV neurons cultured in a microfluidic device. CB, Cell bodies; D, dendrites. Scale bar, $20 \mu \mathrm{m} . \boldsymbol{B}$, A representative dendritic region immunostained for MAP2 and GluN2A. Scale bar, $3 \mu \mathrm{m}$. C, Time-lapse imaging shows microfluidic chambers maintain fluidic isolation throughout the glycine treatment paradigm. Microfluidic devices were filled with PBS (initial), then left-side PBS was replaced with PBS plus Cy3b dye $\left(t_{0}\right)$, and, 30 min later, right-side PBS was replaced with PBS plus Cy5 dye $\left(t_{30}\right)$. After 3 min, PBS plus Cy5 dye was replaced with PBS alone $\left(t_{33}\right)$ and allowed to sit for an additional 30 min $\left(t_{60}\right)$. The Cy3 and Cy5 dye solutions remained restricted to the $C B$ and dendrite (D) sides, respectively, for the duration of the experiment. $\boldsymbol{D}$, Hippocampal neurons were cultured in microfluidic devices. Anisomycin was applied to either the cell body or the dendrite compartment for $30 \mathrm{~min}$, followed by glycine or vehicle application to the dendrite compartment for $3 \mathrm{~min}$, and an additional $30 \mathrm{~min}$ of incubation in solution without glycine. Anisomycin or DMSO was present in all solutions. Then, the neurons were fixed and immunostained for surface GluN2A protein (ANOVA, Bonferroni $t$ tests, $n=65 ;{ }^{*} p<0.001,{ }^{\#} p=0.008$ ). Scale bar, $5 \mu \mathrm{m}$. $E$, Neurons were treated as in $\boldsymbol{D}$, except that total GluN2A was immunostained (ANOVA, Bonferronit tests, $n=65 ;{ }^{*} p=0.003,{ }^{\#} p=0.011,{ }^{\ddagger} p<0.001,{ }^{\phi} p=0.004$ ). Scale bar is $3 \mu \mathrm{m}$. Data are mean \pm SEM.

whether $\mathrm{CPEB}$ and the CPE sequence control dendritic localization of GluN2A mRNA. CPEB expression was reduced in cultured hippocampal neurons using lentiviral shRNA, and knockdown (KD) was confirmed by Western blotting (Fig. 3E). Fluorescence in situ hybridization for endogenous GluN2A mRNA demonstrated that CPEB knockdown reduced the dendritic localization of endogenous GluN2A mRNA by $\sim 50 \%$ (control: $44 \pm 3$ dendritic granules $/ 50 \mu \mathrm{m}^{2}$, CPEB KD: $21 \pm 3$ dendritic granules $/ 50 \mu \mathrm{m}^{2} ; n=25-30$ cells, Student's $t$ test, $p<$ 0.001) (Fig. 3D). CPEB knockdown increased total GluN2A mRNA levels as assessed by quantitative real-time PCR (CPEB KD: $128 \pm 6.6 \%$ of control, $n=5$, paired $t$ test, $p=0.024$ ), indicating that the decrease in dendritic GluN2A mRNA levels was due to impaired localization rather than reduced transcription or mRNA stability. To investigate whether the CPE sequence regulates GluN2A mRNA localization, GFP fused to the GluN2A 3' UTR or $\triangle$ CPE-GluN2A 3' UTR was expressed in cultured hippocampal neurons for $12 \mathrm{~h}$, and then dendritic GFP mRNA levels were examined by FISH. Dendritic GFP mRNA levels were significantly reduced in neurons expressing the $\triangle \mathrm{CPE}$-GluN2A $3^{\prime}$ UTR compared with the wild-type GluN2A 3' UTR (Fig. 3F). The 3' UTR sequence did not significantly affect total GFP mRNA levels, as assessed by quantitative real-time PCR $\left(\triangle \mathrm{CPE}-3^{\prime}\right.$ UTR: $102 \pm 6.0 \%$ of WT-3' UTR, $n=6$, paired $t$ test, $p=0.929$ ). Together, these data indicate that CPEB and the CPE sequence regulate GluN2A mRNA localization to dendrites.
The 3' UTR CPE sequence regulates translation of GluN2A mRNA in dendrites

Next, we evaluated whether GluN2A could be translated at synapses and within dendrites. In synaptoneurosome fractions isolated from mouse hippocampus, the application of glutamate $(100 \mu \mathrm{M})$ and glycine $(50 \mu \mathrm{M})$ for $15 \mathrm{~min}$ induced a protein synthesis-dependent increase in endogenous GluN2A protein levels, suggesting that GluN2A is synthesized at synapses (Fig. $4 A$ ). To study local protein synthesis directly, dendritic mRNA translation was imaged in live neurons using a diffusionrestricted translation reporter Dendra2 fused to the GluN2A 3' UTR, similar to the reporter we previously used to study local translation of $\beta$-actin mRNA (Welshhans and Bassell, 2011). Glycine induced the dendritic synthesis of Dendra2 fused to the GluN2A 3' UTR, but not when the UTR was removed or anisomycin was applied (Fig. 4B). Dendra2 fluorescence levels were significantly increased at $25 \mathrm{~min}$ after glycine application and reached a plateau by $40 \mathrm{~min}$. These data suggest that glycine treatment induces the local translation of GluN2A mRNA in dendrites. In addition, the CPE sequence was required for the GluN2A 3' UTR to mediate glycine-induced dendritic synthesis of Dendra2 (Fig. $4 C$ ). In these experiments, the Dendra2 constructs were expressed for $48 \mathrm{~h}$ before imaging; this expression time resulted in similar dendritic localization of the wild-type and $\triangle \mathrm{CPE} 3^{\prime}$ UTRs under both control and glycine-treated conditions (as assessed by GFP FISH) (Fig. 4D). In Figure 3, we showed that mutation of the CPE sequence significantly reduced 
A

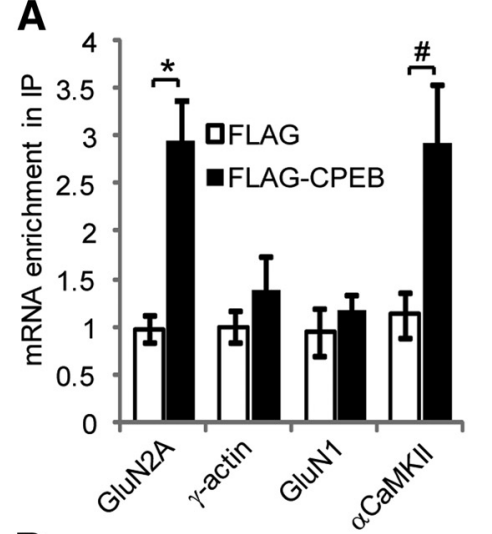

B

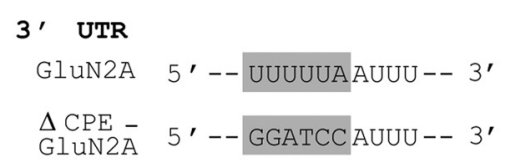

C

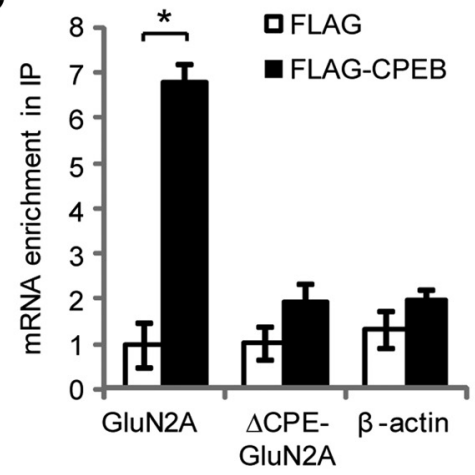

D

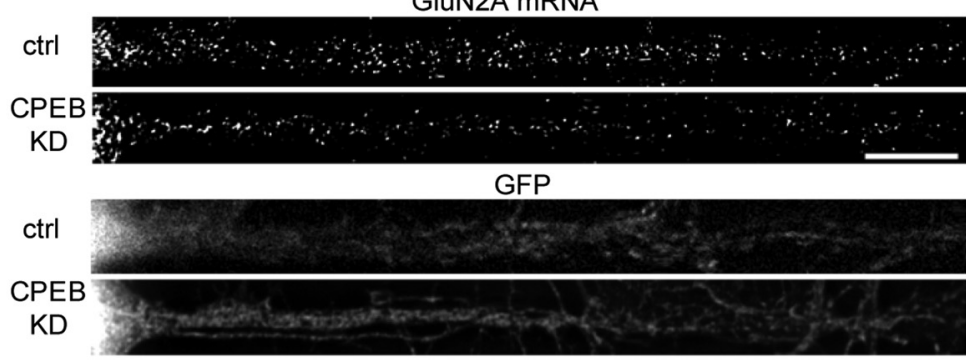

E

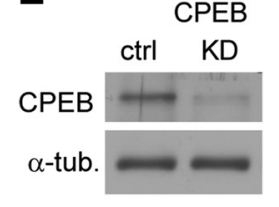

$\mathbf{F}$
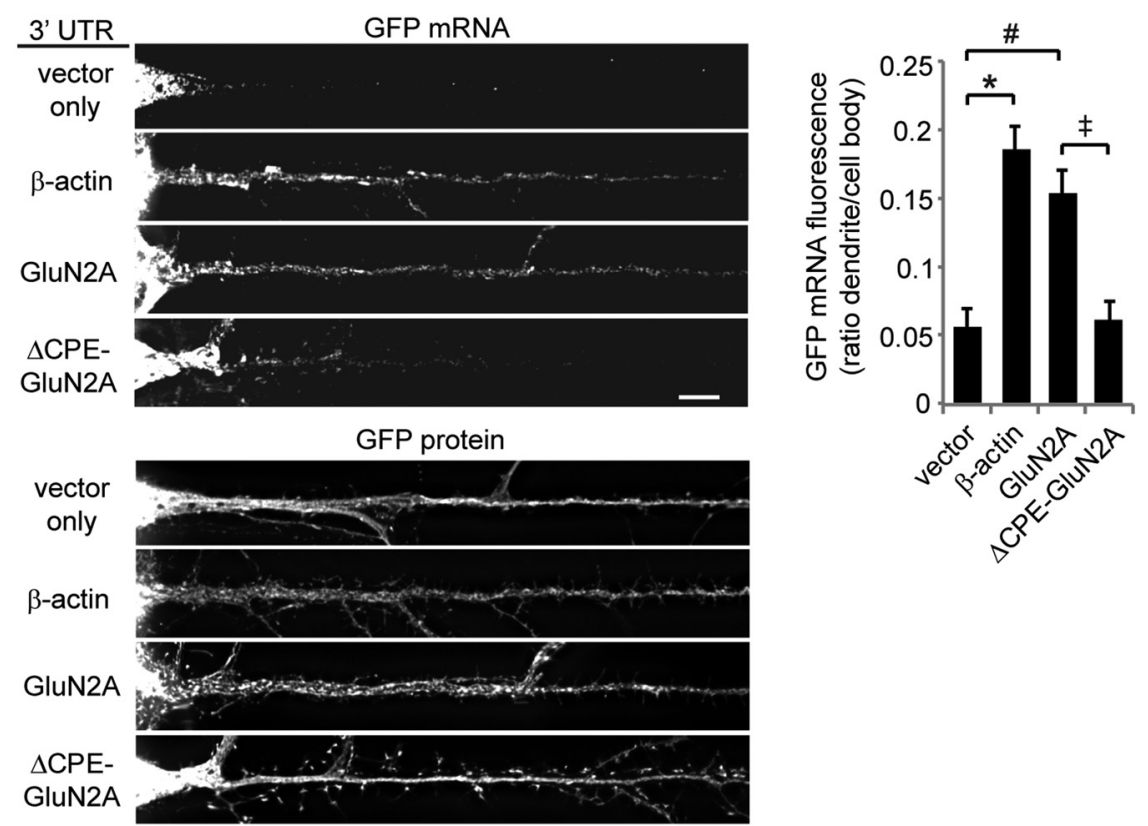

Figure 3. CPEB interacts with endogenous GluN2A mRNA and regulates its dendritic localization. A, FLAG-CPEB or FLAG were immunoprecipitated from hippocampal neuron lysates. GluN2A, $\gamma$-actin, GluN1, and $\alpha$ CaMKII mRNA levels in input and FLAG immunoprecipitates were quantified by real-time PCR. Precipitated mRNA levels were normalized to input levels, and the graphed values were normalized to the FLAG IP/ $\gamma$-actin mRNA group mean (ANOVA, Bonferroni $t$ tests, $n=6$; ${ }^{*} p=0.009,{ }^{\#} p=0.002$ ). $\boldsymbol{B}$, The GluN2A $3^{\prime}$ UTR CPE sequence was mutated as shown. C, Neuroblastoma cells were transfected with either FLAG-CPEB or FLAG and GFP fused to the GluN2A, $\triangle$ CPE-GluN2A, or $\beta$-actin $3^{\prime}$ UTR. GFP mRNA levels in FLAG immunoprecipitates and input samples were quantified by real-time PCR. The graphed values were normalized to the FLAG IP/GluN2A mRNA group mean (ANOVA, Bonferroni $t$ tests, $n=6,{ }^{*} p=0.015$ ). $\boldsymbol{D}$, Hippocampal neurons were treated with control or (PEB shRNA lentiviruses (expressing GFP) for $4 \mathrm{~d}$ and processed for GluN2A mRNA FISH. Dendritic mRNA granules were counted using ImageJ and normalized to the area of the dendritic region. Scale bar, $10 \mu \mathrm{m}$. E, Lysates from hippocampal neurons treated with control or CPEB shRNA were Western blotted for CPEB and $\alpha$-tubulin. $\boldsymbol{F}$, GFP fused to the vector 3' UTR, $\beta$-actin 3' UTR, GluN2A 3' UTR, or $\Delta$ CPE-GluN2A 3' UTR were expressed in neurons for $12 \mathrm{~h}$, then the neurons were fixed and processed for GFP mRNA FISH. Representative images of GFP mRNA FISH and GFP protein fluorescence signals are shown. Scale bar, $10 \mu \mathrm{m}$. Cell body and dendritic fluorescence were quantified and graphed as a ratio of dendritic to cell body fluorescence (ANOVA, Bonferroni $t$ tests, $n=18-25$ cells, $\left.{ }^{*} p=0.001,{ }^{\#} p=0.001,{ }^{\ddagger} p=0.001\right)$. Data are mean \pm SEM.

dendritic localization when the GFP constructs were expressed for only $12 \mathrm{~h}$. These data are consistent with that of all other constructs we have tested including GFP with only the vector 3' UTR, which also show robust dendritic localization after $48 \mathrm{~h}$ of expression (data not shown). These data indicate that Dendra2$\triangle$ CPE-GluN2A $3^{\prime}$ UTR is localized to dendrites during the translation assay ( $48 \mathrm{~h}$ expression), but it does not undergo glycine-induced local translation, suggesting that the CPE sequence is necessary for glycine-induced GluN2A mRNA translation in dendrites.

\section{The CPE sequence and CPEB-associated factors regulate} GluN2A surface expression in dendrites

Finally, we tested whether the CPE sequence and associated translation factors, Gld2 and Ngd, regulate activity-induced GluN2A surface expression. In biotinylation assays, lentiviral shRNA-mediated knockdown of Gld2 reduced the surface and total levels of GluN2A protein at basal state, and blocked the glycine-induced increase in surface and total GluN2A expression (Fig. 5A,B). Ngd knockdown increased the basal level of GluN2A surface expression and potentiated the glycine-induced increase in GluN2A surface expression (Fig. 5C). Ngd knockdown increased basal and glycine-induced total GluN2A levels similarly, as there were significant main effects with Ngd knockdown and glycine treatment, but no significant interaction effect in the ANOVA analysis (Fig. 5C). These data indicate that Gld2 facilitates and Ngd inhibits the activity-induced expression and membrane insertion of GluN2A.

To determine whether these factors regulate dendritic protein synthesis, neurons were cultured in microfluidic devices and treated with Gld2- or Ngd-specific shRNA for 3-4 d. Glycine was added to the dendritic compartment of these microfluidic cultures, and anisomycin was applied to the cell bodies to block somatic protein synthesis (Fig. $5 D$ shows a schematic of the experimental design). Gld2 was required for the glycine-induced increases in GluN2A expression and membrane insertion in den- 
A

$\begin{array}{rrrrr}\text { glu/gly } & - & + & - & + \\ \text { aniso. } & - & - & + & + \\ \text { GluN2A } & - & - & - & - \\ \alpha \text {-tubulin } & - & - & -\end{array}$

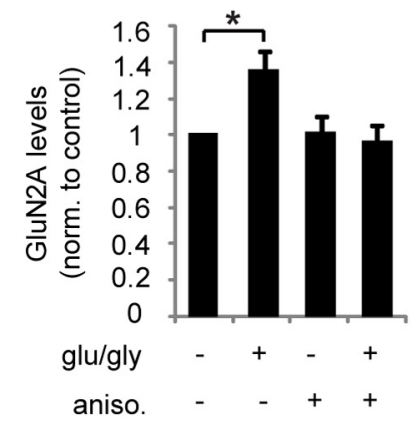

B
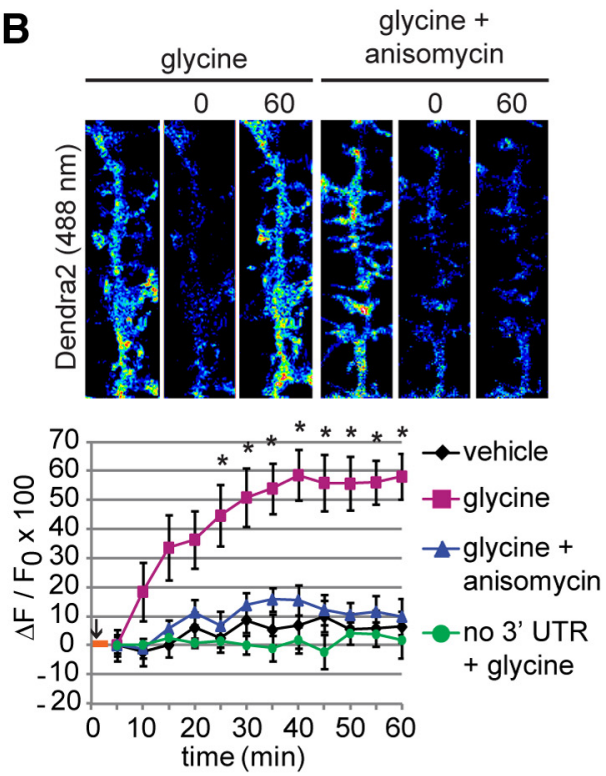

C
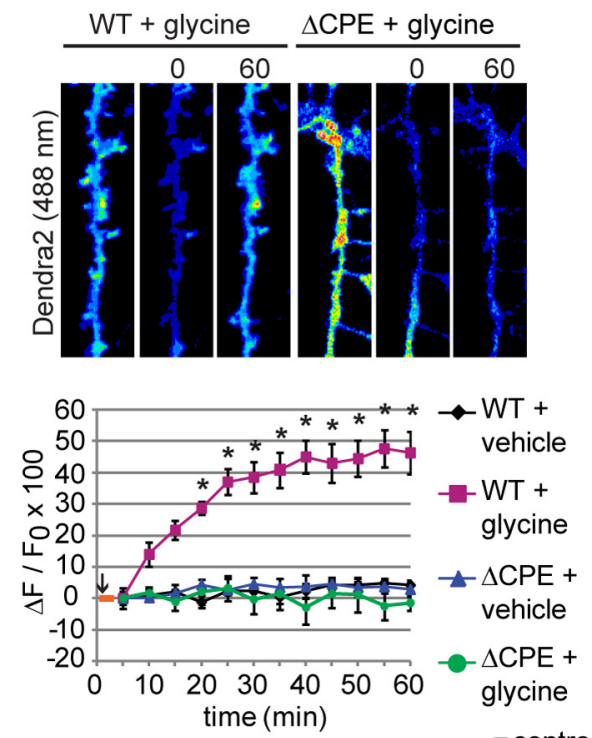
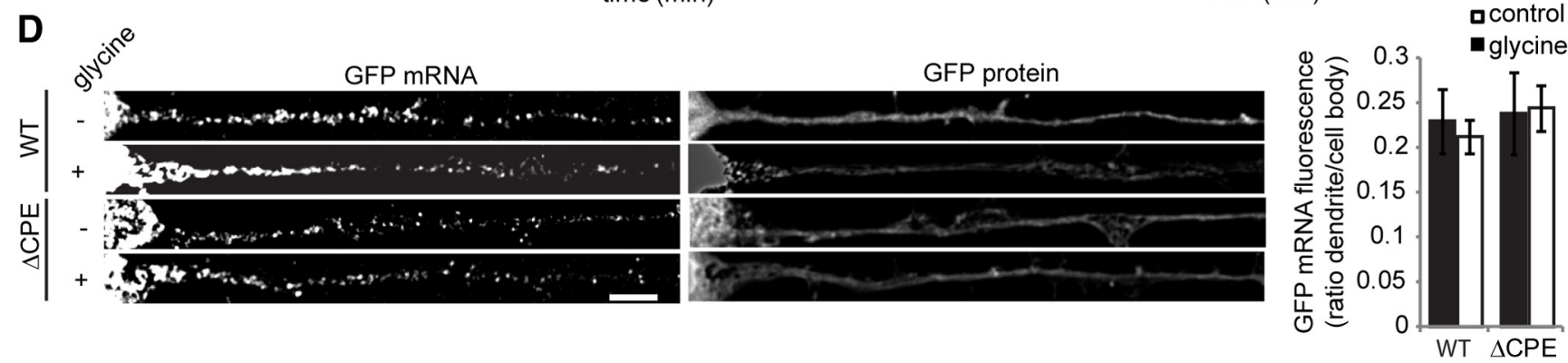

Figure 4. Dendritic GluN2A mRNA translation is mediated by the 3' UTR CPE sequence. $A$, Synaptoneurosome fractions were isolated from mouse hippocampus and pretreated with anisomycin or vehicle, and then glutamate and glycine or vehicle were applied for $15 \mathrm{~min}$. GluN2A and tubulin (loading control) protein levels were analyzed by Western blotting (ANOVA, Bonferronit tests, $n=$ $\left.6 ;{ }^{*} p=0.013\right)$. B, C, Glycine induced dendritic fluorescence recovery of Dendra2 $-3^{\prime}$ UTR, but not Dendra2 alone, Dendra2- $\Delta C P E-3$ ' UTR, or when anisomycin was applied. In the histograms, an orange bar depicts the glycine application, and photoconversion was performed just after start of glycine application (black arrow; RM-ANOVA, Bonferronit tests, $n=10-12 ;{ }^{*} p<0.001$ ). $\boldsymbol{D}$, GFP fused to the GluN2A 3' UTR or $\triangle$ CPE-GluN2A 3' UTR were expressed in neurons for $48 \mathrm{~h}$, then neurons were treated with glycine (or vehicle), fixed, and processed for GFP mRNA FISH. Scale bar, 5 $\mu \mathrm{m}$ ). GFP FISH fluorescence was quantified as above (ANOVA, n.s.; $n=20-24$ cells). Data are mean \pm SEM.

drites; whereas, Ngd knockdown enhanced glycine-induced GluN2A surface expression in dendrites (Fig. $5 E, F$ ). In this immunofluorescence assay, Gld2 and Ngd knockdown did not have a significant impact on basal levels of GluN2A, whereas basal levels were altered in the biotinylation assay (Fig. $5 B, C$ ). This may be due to Western blotting being a more sensitive technique than immunofluorescence, or perhaps this result suggests that basal GluN2A levels in distal dendrites $(>200 \mu \mathrm{m}$ from the cell body) are regulated differently than the somatic pool, which likely contributes a majority of the protein detected by biotinylation. Given that glycine-induced insertion of GluN2A in the dendritic compartment is dependent specifically on dendritic protein synthesis, these data suggest that Gld2 and Ngd bidirectionally regulate GluN2A synthesis and surface expression via dendritic mRNA regulation.

It is possible that the shRNA-mediated knockdown of Gld2 and Ngd regulated GluN2A expression through a mechanism independent of CPEB or the CPE sequence, as the depletion of these proteins is known to alter synaptic plasticity (Udagawa et al., 2012). Thus, we sought to determine whether GluN2A surface expression in dendrites is dependent on posttranscriptional regulation of GluN2A mRNA. To do so, we used the pH-sensitive fluorescent protein SEP fused to the GluN2A coding region and either the wild-type or $\triangle \mathrm{CPE}$ GluN2A 3' UTR. Because SEP is only fluorescent when expressed on the cell surface (Royle et al.,
2008), we could assay whether mutating the $3^{\prime}$ UTR CPE sequence directly affected GluN2A surface expression. Time-lapse imaging of surface SEP-GluN2A fluorescence revealed a significant increase in dendritic GluN2A surface expression $10 \mathrm{~min}$ after glycine treatment, and the CPE sequence was required for this glycineinduced insertion of GluN2A (Fig. 6). These data indicate that the CPE sequence, and likely the associated translation factors, can control glycine-induced GluN2A membrane insertion in dendrites via direct regulation of GluN2A mRNA.

\section{Discussion}

This study establishes a novel role for dendritic protein synthesis in regulating activity-dependent NMDA receptor expression. Using microfluidic devices, we discovered that dendritic protein synthesis was necessary and sufficient for glycine-induced expression and membrane insertion of endogenous GluN2A. Furthermore, a CPE-dependent mechanism mediated dendritic localization and local translation of GluN2A mRNA. This posttranscriptional mechanism also regulated activity-induced surface expression of GluN2A protein in dendrites. Thus, we propose that activity-induced membrane insertion of GluN2Acontaining NMDA receptors is one means by which dendritic protein synthesis regulates glutamatergic synapses.

Several studies have focused on the dendritic synthesis of AMPA receptors as changes in AMPA receptor expression and 
A

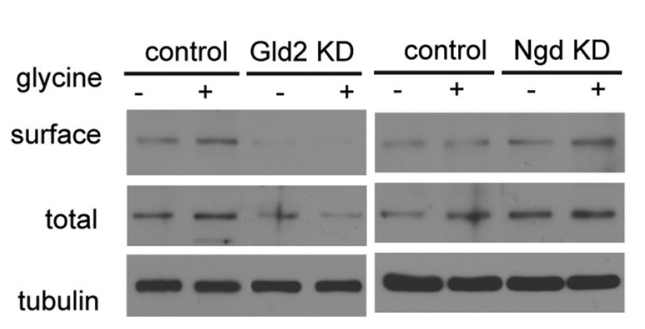

D

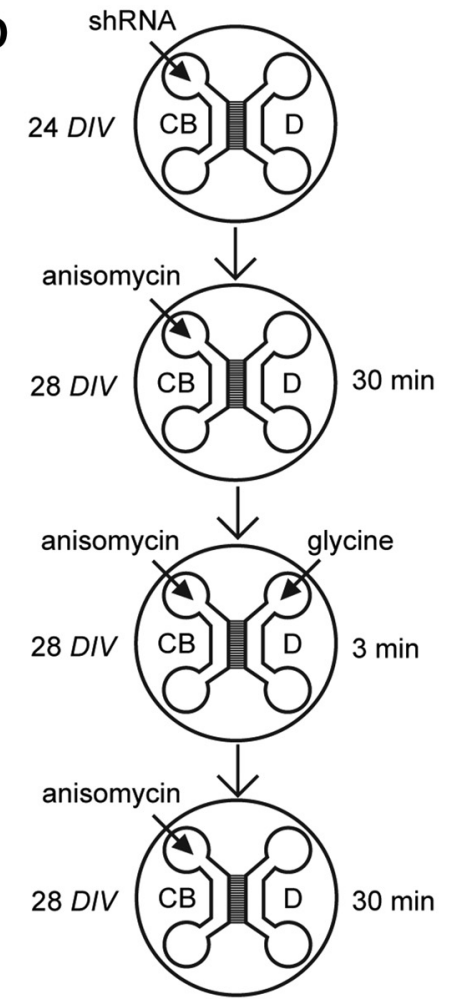

$\mathbf{E}$

$\mathbf{F}$
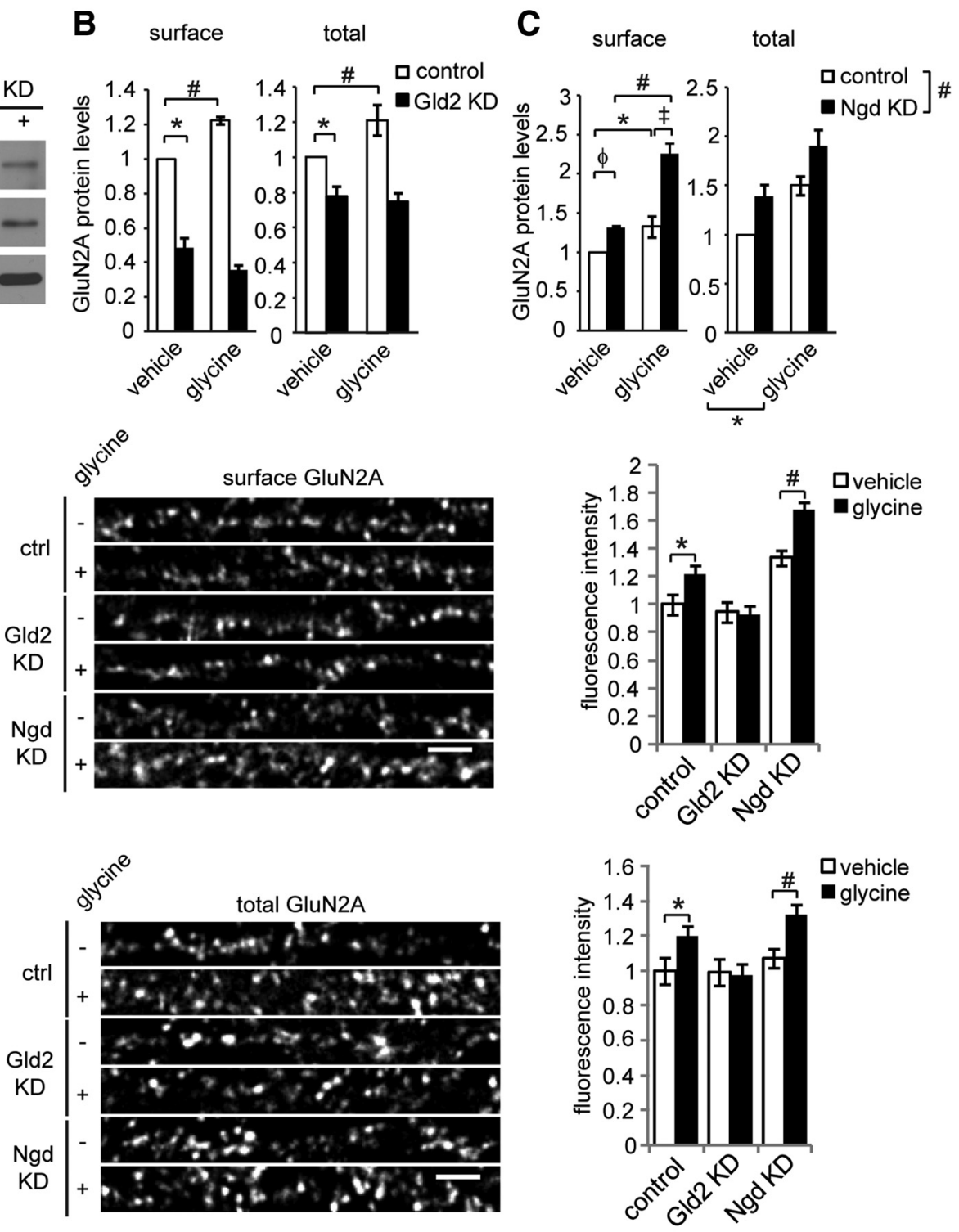
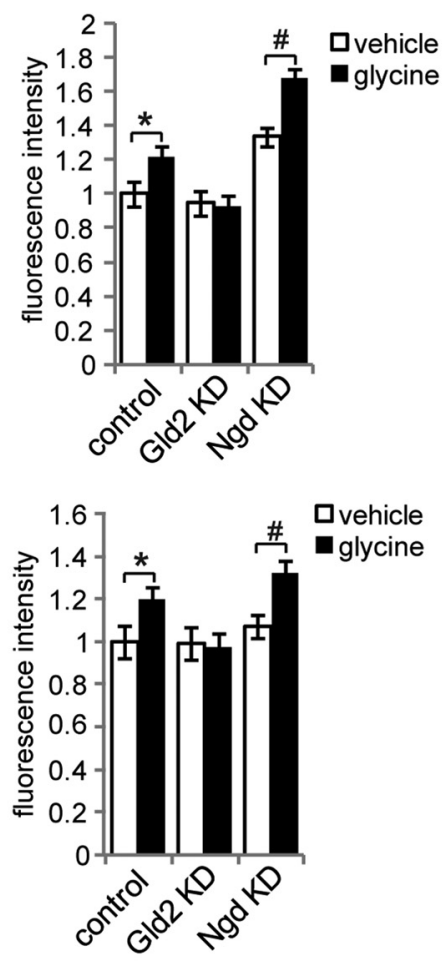

Figure 5. Gld2 and Ngd regulate glycine-induced GluN2A synthesis and surface expression in dendrites. A, Hippocampal neurons were treated with control, Gld2 shRNA, or Ngd shRNA for $3-4$ $d$, and stimulated with glycine or vehicle. Surface proteins were biotinylated, and total and surface proteins were immunoblotted for GluN2A and $\alpha$-tubulin (loading control). Protein levels were quantified by densitometry (two-way ANOVA, posthoc Bonferronittests, $n=6 ; B$, GId2 KD effects on basal and glycine-induced labeling of surface: ${ }^{*} p=0.001,{ }^{\#} p=0.007 ;$ total: ${ }^{*} p=0.015,{ }^{\#} p=$

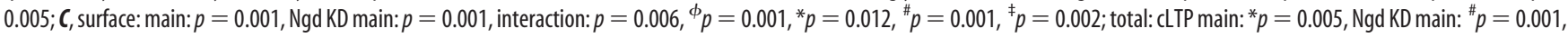
interaction:0.940). D, A schematic showing neuron culture and treatment in microfluidic devices. Lentiviral shRNA was applied to the CB compartment at 24 DIV, and the cultures were used $3-4 \mathrm{~d}$ later. For glycine treatment, anisomycin was applied to the CB compartment 30 min before glycine treatment (applied to dendrites only). Glycine was applied for 3 min then removed; anisomycin was present in the $C B$ compartment throughout the experiment. $\boldsymbol{E}, \boldsymbol{F}$, Hippocampal neurons were fixed in the microfluidic devices, and then immunostained for MAP2 and either $(\boldsymbol{E})$ surface or $(\boldsymbol{F})$ total GluN2A (two-way ANOVA, Bonferroni $t$ tests; $\boldsymbol{E}, n=40-45,{ }^{*} p=0.015,{ }^{\sharp} p=0.012 ; \boldsymbol{F}, n=40-45,{ }^{*} p=0.012,{ }^{\sharp} p=0.006$ ). Scale bars, $3 \mu \mathrm{m}$. Data are mean \pm SEM.

membrane insertion contribute to long-term synaptic plasticity (Kacharmina et al., 2000; Ju et al., 2004; Smith et al., 2005; Grooms et al., 2006; Sutton et al., 2006; Maghsoodi et al., 2008; Kessels and Malinow, 2009; Soden and Chen, 2010). However, synaptic activity also regulates NMDA receptor expression and membrane insertion (Lau and Zukin, 2007; Yashiro and Philpot, 2008). We focused on the translational regulation of the GluN2A subunit because GluN2A mRNA is localized to dendrites (Cajigas et al., 2012; Udagawa et al., 2012), and the expression and membrane insertion of GluN2A have been shown to increase during LTP (Williams et al., 1998; Grosshans et al., 2002). Herein, we show that glycine treatment leads to GluN2A membrane insertion in hippocampal neurons. Moreover, we discovered that dendritic protein synthesis is required for the glycine-induced expression and membrane insertion of endogenous GluN2A. Notably, somatic protein synthesis was not sufficient for activityinduced GluN2A membrane insertion in dendrites, although somatic protein synthesis did regulate basal levels of dendritic GluN2A protein. These data suggest a model whereby local protein synthesis is necessary and sufficient for at least some forms of activity-induced GluN2A expression and membrane insertion in dendrites, whereas constitutive expression of dendritic GluN2A requires somatic protein synthesis (Fig. 7). A previous study found no change in NMDA receptor-mediated currents following glycine treatment (Lu et al., 2001). In that study, the neurons were cultured for 12-17 d, whereas neurons were cultured for 21-28 d in our study. The different culture times could have caused this discrepancy as activity-induced NMDA receptor in- 

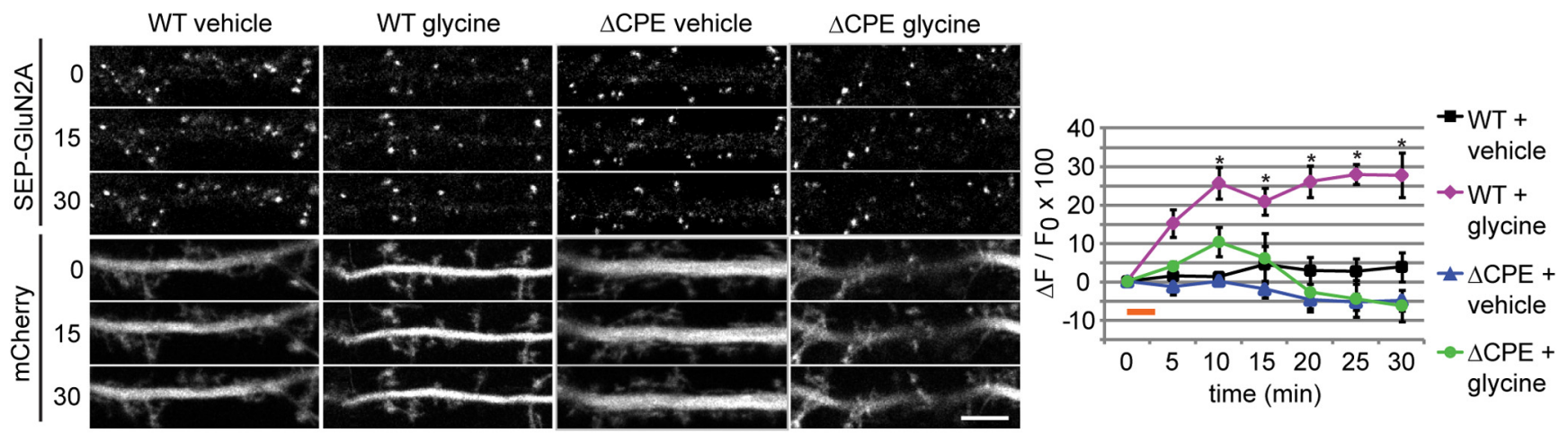

Figure 6. The CPE sequence controls GluN2A surface expression in dendrites. SEP-GluN2A-3' UTR or SEP-GluN2A- $\Delta$ CPE-3' UTR along with mCherry (to visualize the entire neuron) were expressed in cultured hippocampal neurons for $18-24 \mathrm{~h}$. Scale bar, $5 \mu \mathrm{m}$. Glycine or vehicle was applied for $3 \mathrm{~min}$ (orange bar), and the neurons were imaged every $5 \mathrm{~min}$ for $30 \mathrm{~min}$ (RM-ANOVA, Bonferroni $t$ tests, $n=5-8$ cells; $\left.{ }^{*} p<0.009\right)$. Data are mean \pm SEM.

sertion has been shown to be more robust later in development (Grosshans et al., 2002). Alternatively, the newly inserted NMDA receptors observed herein may be extrasynaptic, and therefore would not have been detected in the previous study (Thomas et al., 2006). In future studies, it would be interesting to measure the synaptic versus extrasynaptic localization of newly inserted NMDA receptors as well as extrasynaptic NMDA receptor currents after glycine treatment.

Although several locally synthesized proteins could regulate NMDA receptor insertion, our data suggest that locally synthesized GluN2A likely contributes to the glycine-induced surface expression of GluN2A-containing NMDA receptors. In this regard, we show that: (1) dendritic protein synthesis is necessary for glycineinduced dendritic GluN2A protein expression, (2) GluN2A protein is synthesized in synaptoneurosomes, (3) the GluN2A 3' UTR regulates dendritic translation of a reporter protein, and (4) the GluN2A 3' UTR regulates surface expression of a GluN2A fusion protein. Together, these findings support the assertion that GluN2A is synthesized within dendrites in an activitydependent manner. Our findings are consistent with previous reports showing Golgi outposts and a satellite secretory pathways in spines (Pierce et al., 2001; Horton and Ehlers, 2003), which could mediate the membrane insertion of locally synthesized proteins. More work is needed to understand the cellular components that couple local translation of receptors to their insertion in the plasma membrane.

Previous reports have shown that synaptic receptors can be locally synthesized and inserted into the plasma membrane, but the posttranscriptional mechanisms regulating these processes have not been reported. Our data support a role for a 3' UTR CPE sequence and the $\mathrm{CPEB}$-associated translation complex in regulating the local synthesis and insertion of GluN2A. To our knowledge, these data are the first to describe a localized posttranscriptional mechanism that controls the activity-induced expression and membrane insertion of synaptic receptors. We propose that $\mathrm{CPEB}$ has a dual role in regulating the dendritic synthesis of GluN2A: CPEB regulates the dendritic localization of GluN2A mRNA and the activity-dependent translation of GluN2A mRNA in dendrites. Our live-imaging experiments using SEP-GluN2A fused to the GluN2A 3' UTR indicate that CPEB also regulates glycine-induced membrane insertion of GluN2A. Because we found that dendritic protein synthesis was necessary for glycine-induced insertion of endogenous GluN2A (Fig. 2), we propose that some of the inserted SEP-GluN2A molecules (Fig. 6 ) were synthesized within dendrites during the time course analyzed (0-30 $\mathrm{min})$. However, given the time necessary for synthesis, assembly, and trafficking of NMDA receptors, it is likely that receptors inserted within 5 min after glycine treatment had 
been previously synthesized. The $\mathrm{CPE}$ sequence was required for glycine-induced SEP-GluN2A insertion, therefore we postulate that the CPE mutation likely blocked glycine-induced local synthesis of SEP-GluN2A. In addition, the CPE mutation likely reduced the preexisting pool of dendritic SEP-GluN2A protein available to traffic in response to glycine. This effect could be due to reduced basal mRNA localization or local translation of SEPGluN2A, or reduced somatic synthesis and trafficking of SEPGluN2A. Currently, we cannot distinguish between dendritic and somatic effects of the CPE. Future studies combining microfluidic devices with translation reporters and/or SEP-GluN2A could be used to delineate these mechanisms. Nonetheless, our data show that activity-regulated surface expression of GluN2A requires a cis-acting mRNA sequence, which has established roles in mRNA localization and local translation.

These findings have important implications for studies of activity-induced trafficking of recombinant receptor proteins. In most cases, these plasmid-based experiments use only the protein coding sequence and not the untranslated regions. Our data show that activity-dependent GluN2A insertion is regulated by the 3' UTR. Although untranslated sequences do not directly regulate interactions between the coded protein and trafficking partners, these sequences are necessary for proper subcellular protein expression and, therefore might be critical for localized regulation, as described herein, or to expose the nascent protein to the appropriate binding partners or regulatory proteins.

Dendritic protein synthesis has been proposed to be a means for input-specific protein delivery during synaptic plasticity. We recently reported that the CPEB-associated translation complex is present within dendritic spines (Udagawa et al., 2012). Thus, it is possible that these translation factors could regulate GluN2A synthesis at specific synapses. This CPEB-dependent regulation also provides a reversible mechanism, which allows for translational repression during mRNA transport and local translational activation beneath the synapse. We previously showed that glycine induces $\mathrm{CPEB}$ phosphorylation and mRNA polyadenylation in dendrites (Udagawa et al., 2012). We also showed that the CPEB-associated translation factors Gld2 and Ngd bidirectionally regulate LTP and GluN2A protein expression, but whether these effects were mediated by dendritic and/or somatic protein synthesis was not examined. Importantly, in the current study, we demonstrated that Gld2 and Ngd bidirectionally regulate activity-induced synthesis and surface levels of GluN2A in dendrites. Altogether, these findings suggest that the CPEBassociated complex can repress translation in dendrites until synaptic activity induces Gld2-dependent GluN2A synthesis. The observation that glycine treatment increases GluN2A expression even when Ngd is depleted suggests that additional factors control activity-induced GluN2A translation, one such factor might be the CPEB-associated deadenylase PARN (Udagawa et al., 2012). PARN is likely present complexes containing GluN2A mRNA as it is known to interact with CPEB and Gld2. Future studies are needed to discern the roles of these two translational repressors in regulating GluN2A synthesis.

In addition, the differential expression of GluN2A and GluN2B subunits critically regulate neuronal function (MacDonald et al., 2006; Yashiro and Philpot, 2008; Smith et al., 2009). Herein, glycine treatment increased GluN2A synthesis and surface expression, but GluN2B levels were unaffected. Therefore, this CPEB-mediated mechanism is also a means for modulating NMDA receptor expression in a subunit-specific manner. Interestingly, glycine treatment increased the total levels of GluN1 protein, but no CPE-like se- quences were found in the GluN1 3' UTR, and GluN1 mRNA did not associate with CPEB in our pull-down assays. Thus, GluN1 synthesis is likely mediated by a CPEB-independent mechanism. GluN1 mRNA is localized to dendrites, and dendritic GluN1 mRNA levels are increased during injury-induced synaptogenesis in the dentate gyrus (Miyashiro et al., 1994; Benson, 1997; Gazzaley et al., 1997; Cajigas et al., 2012). Posttranscriptional mechanisms regulating GluN1 mRNA stability and translation have been identified (Kumari, 2001; Anji and Kumari, 2006, 2011), but a mechanism for GluN1 mRNA transport and local translation has not been reported.

Increasing evidence indicates that NMDA receptors are not unlike AMPA receptors in that they are dynamically regulated at synapses (Lau and Zukin, 2007; Rebola et al., 2010). Herein, we show that local protein synthesis is necessary for one form of activity-dependent NMDA receptor insertion in dendrites, whereas somatic protein synthesis did not contribute to activityinduced NMDA receptor insertion in dendrites. These data indicate that dendritic protein synthesis might be a key regulator of activity-dependent NMDA receptor expression. Given the crucial role of NMDA receptors in brain development, plasticity, and disease, this study motivates further work to investigate how dendritic protein synthesis and specific posttranscriptional mechanisms control NMDA receptor function.

\section{References}

Anji A, Kumari M (2006) A novel RNA binding protein that interacts with NMDA R1 mRNA: regulation by ethanol. Eur J Neurosci 23:2339-2350. CrossRef Medline

Anji A, Kumari M (2011) A cis-acting region in the $N$-methyl-d-aspartate R1 3'-untranslated region interacts with the novel RNA-binding proteins beta subunit of alpha glucosidase II and annexin A2: effect of chronic ethanol exposure in vivo. Eur J Neurosci 34:1200-1211. CrossRef Medline

Benson DL (1997) Dendritic compartmentation of NMDA receptor mRNA in cultured hippocampal neurons. Neuroreport 8:823-828. CrossRef Medline

Cajigas IJ, Tushev G, Will TJ, tom Dieck S, Fuerst N, Schuman EM (2012) The local transcriptome in the synaptic neuropil revealed by deep sequencing and high-resolution imaging. Neuron 74:453-466. CrossRef Medline

Cracco JB, Serrano P, Moskowitz SI, Bergold PJ, Sacktor TC (2005) Protein synthesis-dependent LTP in isolated dendrites of CA1 pyramidal cells. Hippocampus 15:551-556. CrossRef Medline

Derkach VA, Oh MC, Guire ES, Soderling TR (2007) Regulatory mechanisms of AMPA receptors in synaptic plasticity. Nat Rev Neurosci 8:101113. CrossRef Medline

Ehlers MD (2000) Reinsertion or degradation of AMPA receptors determined by activity-dependent endocytic sorting. Neuron 28:511-525. CrossRef Medline

Gazzaley AH, Benson DL, Huntley GW, Morrison JH (1997) Differential subcellular regulation of NMDAR1 protein and mRNA in dendrites of dentate gyrus granule cells after perforant path transection. J Neurosci 17:2006-2017. Medline

Goslin K, Banker G (1998) Culturing nerve cells, Ed 2. Cambridge, MA: MIT.

Grooms SY, Noh KM, Regis R, Bassell GJ, Bryan MK, Carroll RC, Zukin RS (2006) Activity bidirectionally regulates AMPA receptor mRNA abundance in dendrites of hippocampal neurons. J Neurosci 26:8339-8351. CrossRef Medline

Grosshans DR, Clayton DA, Coultrap SJ, Browning MD (2002) LTP leads to rapid surface expression of NMDA but not AMPA receptors in adult rat CA1. Nat Neurosci 5:27-33. CrossRef Medline

Hollingsworth EB, McNeal ET, Burton JL, Williams RJ, Daly JW, Creveling CR (1985) Biochemical characterization of a filtered synaptoneurosome preparation from guinea pig cerebral cortex: cyclic adenosine $3^{\prime}: 5^{\prime}$ monophosphate-generating systems, receptors, and enzymes. J Neurosci 5:2240-2253. Medline

Horton AC, Ehlers MD (2003) Dual modes of endoplasmic reticulum-to- 
Golgi transport in dendrites revealed by live-cell imaging. J Neurosci 23:6188-6199. Medline

Huang YS, Carson JH, Barbarese E, Richter JD (2003) Facilitation of dendritic mRNA transport by CPEB. Genes Dev 17:638-653. CrossRef Medline

Huang YY, Kandel ER (2005) Theta frequency stimulation induces a local form of late phase LTP in the CA1 region of the hippocampus. Learn Mem 12:587-593. CrossRef Medline

Ju W, Morishita W, Tsui J, Gaietta G, Deerinck TJ, Adams SR, Garner CC, Tsien RY, Ellisman MH, Malenka RC (2004) Activity-dependent regulation of dendritic synthesis and trafficking of AMPA receptors. Nat Neurosci 7:244-253. CrossRef Medline

Kacharmina JE, Job C, Crino P, Eberwine J (2000) Stimulation of glutamate receptor protein synthesis and membrane insertion within isolated neuronal dendrites. Proc Natl Acad Sci U S A 97:11545-11550. CrossRef Medline

Kang H, Schuman EM (1996) A requirement for local protein synthesis in neurotrophin-induced hippocampal synaptic plasticity. Science 273: 1402-1406. CrossRef Medline

Kessels HW, Malinow R (2009) Synaptic AMPA receptor plasticity and behavior. Neuron 61:340-350. CrossRef Medline

Kopec CD, Li B, Wei W, Boehm J, Malinow R (2006) Glutamate receptor exocytosis and spine enlargement during chemically induced long-term potentiation. J Neurosci 26:2000-2009. CrossRef Medline

Kumari M (2001) Differential effects of chronic ethanol treatment on $\mathrm{N}$-methyl-D-aspartate R1 splice variants in fetal cortical neurons. J Biol Chem 276:29764-29771. CrossRef Medline

Kwon HB, Castillo PE (2008) Role of glutamate autoreceptors at hippocampal mossy fiber synapses. Neuron 60:1082-1094. CrossRef Medline

Lau CG, Zukin RS (2007) NMDA receptor trafficking in synaptic plasticity and neuropsychiatric disorders. Nat Rev Neurosci 8:413-426. CrossRef

Lu W, Man H, Ju W, Trimble WS, MacDonald JF, Wang YT (2001) Activation of synaptic NMDA receptors induces membrane insertion of new AMPA receptors and LTP in cultured hippocampal neurons. Neuron 29:243-254. CrossRef Medline

MacDonald JF, Jackson MF, Beazely MA (2006) Hippocampal long-term synaptic plasticity and signal amplification of NMDA receptors. Crit Rev Neurobiol 18:71-84. CrossRef Medline

Maghsoodi B, Poon MM, Nam CI, Aoto J, Ting P, Chen L (2008) Retinoic acid regulates RARalpha-mediated control of translation in dendritic RNA granules during homeostatic synaptic plasticity. Proc Natl Acad Sci U S A 105:16015-16020. CrossRef Medline

Miyashiro K, Dichter M, Eberwine J (1994) On the nature and differential distribution of mRNAs in hippocampal neurites: implications for neuronal functioning. Proc Natl Acad Sci U S A 91:10800-10804. CrossRef Medline

Muddashetty RS, Kelić S, Gross C, Xu M, Bassell GJ (2007) Dysregulated metabotropic glutamate receptor-dependent translation of AMPA receptor and postsynaptic density-95 mRNAs at synapses in a mouse model of fragile X syndrome. J Neurosci 27:5338-5348. CrossRef Medline

Park M, Salgado JM, Ostroff L, Helton TD, Robinson CG, Harris KM, Ehlers MD (2006) Plasticity-induced growth of dendritic spines by exocytic trafficking from recycling endosomes. Neuron 52:817-830. CrossRef Medline

Peng Y, Zhao J, Gu QH, Chen RQ, Xu Z, Yan JZ, Wang SH, Liu SY, Chen Z, $\mathrm{Lu}$ W (2010) Distinct trafficking and expression mechanisms underlie LTP and LTD of NMDA receptor-mediated synaptic responses. Hippocampus 20:646-658. CrossRef Medline

Philpot BD, Cho KK, Bear MF (2007) Obligatory role of NR2A for metaplasticity in visual cortex. Neuron 53:495-502. CrossRef Medline

Pierce JP, Mayer T, McCarthy JB (2001) Evidence for a satellite secretory pathway in neuronal dendritic spines. Curr Biol 11:351-355. CrossRef Medline

Quinlan EM, Philpot BD, Huganir RL, Bear MF (1999) Rapid, experiencedependent expression of synaptic NMDA receptors in visual cortex in vivo. Nat Neurosci 2:352-357. CrossRef Medline

Rebola N, Lujan R, Cunha RA, Mulle C (2008) Adenosine A2A receptors are essential for long-term potentiation of NMDA-EPSCs at hippocampal mossy fiber synapses. Neuron 57:121-134. CrossRef Medline
Rebola N, Srikumar BN, Mulle C (2010) Activity-dependent synaptic plasticity of NMDA receptors. J Physiol 588:93-99. CrossRef Medline

Royle SJ, Granseth B, Odermatt B, Derevier A, Lagnado L (2008) Imaging phluorin-based probes at hippocampal synapses. Methods Mol Biol 457: 293-303. CrossRef Medline

Santos SD, Carvalho AL, Caldeira MV, Duarte CB (2009) Regulation of AMPA receptors and synaptic plasticity. Neuroscience 158:105-125. CrossRef Medline

Scheetz AJ, Nairn AC, Constantine-Paton M (2000) NMDA receptormediated control of protein synthesis at developing synapses. Nat Neurosci 3:211-216. CrossRef Medline

Smith GB, Heynen AJ, Bear MF (2009) Bidirectional synaptic mechanisms of ocular dominance plasticity in visual cortex. Philos Trans R Soc Lond B Biol Sci 364:357-367. CrossRef Medline

Smith WB, Starck SR, Roberts RW, Schuman EM (2005) Dopaminergic stimulation of local protein synthesis enhances surface expression of GluR1 and synaptic transmission in hippocampal neurons. Neuron 45: 765-779. CrossRef Medline

Soden ME, Chen L (2010) Fragile X protein FMRP is required for homeostatic plasticity and regulation of synaptic strength by retinoic acid. J Neurosci 30:16910-16921. CrossRef Medline

Sutton MA, Schuman EM (2006) Dendritic protein synthesis, synaptic plasticity, and memory. Cell 127:49-58. CrossRef Medline

Sutton MA, Ito HT, Cressy P, Kempf C, Woo JC, Schuman EM (2006) Miniature neurotransmission stabilizes synaptic function via tonic suppression of local dendritic protein synthesis. Cell 125:785-799. CrossRef Medline

Swanger SA, Bassell GJ, Gross C (2011) High-resolution fluorescence in situ hybridization to detect mRNAs in neuronal compartments in vitro and in vivo. Methods Mol Biol 714:103-123. CrossRef Medline

Taylor AM, Blurton-Jones M, Rhee SW, Cribbs DH, Cotman CW, Jeon NL (2005) A microfluidic culture platform for CNS axonal injury, regeneration and transport. Nat Methods 2:599-605. CrossRef Medline

Thomas CG, Miller AJ, Westbrook GL (2006) Synaptic and extrasynaptic NMDA receptor NR2 subunits in cultured hippocampal neurons. J Neurophysiol 95:1727-1734. CrossRef Medline

Traynelis SF, Wollmuth LP, McBain CJ, Menniti FS, Vance KM, Ogden KK, Hansen KB, Yuan H, Myers SJ, Dingledine R (2010) Glutamate receptor ion channels: structure, regulation, and function. Pharmacol Rev 62:405496. CrossRef Medline

Udagawa T, Swanger SA, Takeuchi K, Kim JH, Nalavadi V, Shin J, Lorenz LJ, Zukin RS, Bassell GJ, Richter JD (2012) Bidirectional control of mRNA translation and synaptic plasticity by the cytoplasmic polyadenylation complex. Mol Cell 47:253-266. CrossRef Medline

Vickers CA, Dickson KS, Wyllie DJ (2005) Induction and maintenance of late-phase long-term potentiation in isolated dendrites of rat hippocampal CA1 pyramidal neurones. J Physiol 568:803-813. CrossRef Medline

Wells DG, Dong X, Quinlan EM, Huang YS, Bear MF, Richter JD, Fallon JR (2001) A role for the cytoplasmic polyadenylation element in NMDA receptor-regulated mRNA translation in neurons. J Neurosci 21:9541-9548. Medline

Welshhans K, Bassell GJ (2011) Netrin-1-induced local beta-actin synthesis and growth cone guidance requires zipcode binding protein 1 . J Neurosci 31:9800-9813. CrossRef Medline

Williams JM, Mason-Parker SE, Abraham WC, Tate WP (1998) Biphasic changes in the levels of $N$-methyl-D-aspartate receptor-2 subunits correlate with the induction and persistence of long-term potentiation. Brain Res Mol Brain Res 60:21-27. CrossRef Medline

Williams JM, Guévremont D, Kennard JT, Mason-Parker SE, Tate WP, Abraham WC (2003) Long-term regulation of $N$-methyl-D-aspartate receptor subunits and associated synaptic proteins following hippocampal synaptic plasticity. Neuroscience 118:1003-1013. CrossRef Medline

Yashiro K, Philpot BD (2008) Regulation of NMDA receptor subunit expression and its implications for LTD, LTP, and metaplasticity. Neuropharmacology 55:1081-1094. CrossRef Medline

Zhong WX, Dong ZF, Tian M, Cao J, Xu L, Luo JH (2006) N-methyl-Daspartate receptor-dependent long-term potentiation in CA1 region affects synaptic expression of glutamate receptor subunits and associated proteins in the whole hippocampus. Neuroscience 141:1399-1413. CrossRef Medline 